\section{Contraceptive use and associated factors among adolescents on Santiago Island - Cape Verde - Western Africa}

\section{Uso de métodos anticoncepcionais e fatores associados em adolescentes da Ilha de Santiago - Cabo Verde - África Ocidental}

Carlos Mendes Tavares 1

Néia Schor 2

Ivan França Junior 3
1-3 Faculdade de Saúde Pública. Universidade de São Paulo. Av. Dr. Arnaldo, 715, 20 andar, sala 218. Cerqueira César. São Paulo, SP, Brasil. CEP: 01246-904. E-mail: neschor@usp.br

\begin{abstract}
Objective: to estimate the prevalence of contraceptive use and associated factors among adolescents attending public schools on Santiago Island, Cape Verde.

Methods: a cross-sectional study was carried out with 368 sexually active adolescents aged 13-17 years attending eight public elementary and high schools, randomly selected, on Santiago Island, Cape Verde, between January and March 2007. Poisson regression with robust variance was used for the multiple analysis of risk factors, at a 5\% level of significance.

Results: among 368 adolescents, $69.3 \%$ reported having used a contraceptive method during the last act of sexual intercourse. The most frequently used method were condom (94.9\%) and pill (26.4\%). Factors significantly and positively associated with contraceptive use were: living in the capital (PR=1.23; C195\%: 1.07;1.39); having dated and had sexual intercourse ( $P R=1.53 ; C 195 \%: 1.14 ; 2.06)$; and having more than nine years of schooling (PR=1.19; CI 95\%: 1.02; 1.38)

Conclusions: more educated adolescents who studied in Praia (the capital city) and were dating at the time of the study were more likely to use contraception. The high prevalence of condom use and the association between contraception use and years of schooling among adolescents may indicate that sexual and reproductive health policies have produced positive outcomes that may account for the decrease in HIV infection.
\end{abstract}

Key words Sexual initiation, Sexual and reproductive health, Cape Verde, Africa, Western

\section{Resumo}

Objetivo: estimar a prevalência do uso de métodos anticoncepcionais (MAC) e fatores associados entre adolescentes de escola pública na ilha de Santiago em Cabo Verde.

Métodos: estudo transversal, realizado entre janeiro e março de 2007, com amostra aleatória de 368 adolescentes de 13 a 17 anos de idade, com vida sexual ativa, provenientes de oito escolas secundárias públicas da ilha de Santiago. Para análise múltipla dos fatores de risco foi utilizada a regressão de Poisson ajustada pela estimativa robusta de variância considerando-se nivel de significância de 5\%.

Resultados: entre os 368 adolescentes, 69,3\% (255) referiram ter usado MAC na última relação sexual. Os mais frequentes foram o preservativo $(94,9 \%)$ e a pilula $(26,4 \%)$. Fatores significativa e positivamente associados ao uso de MAC foram: morar na capital ( $R P=1,23$; IC95\%: 1,07;1,39), ter namorado e manter relações sexuais com ele(a) $(R P=1,53$; IC95\%: 1,14;2,06) e escolaridade maior que nove anos de estudo (RP=1,19; IC95\%: 1,02; 1,38).

Conclusões: os adolescentes com mais escolaridade, que estudavam na cidade da Praia (capital) $e$ que namoravam na época da entrevista apresentaram maior possibilidade de uso de um MAC. O elevado uso de preservativo e a associação entre escolaridade e utilização de MAC entre adolescentes podem expressar resultados positivos das politicas de saúde sexual e reprodutiva atuais, contribuindo para diminuição da infecção por HIV.

Palavras-chave Início da vida sexual, Saúde sexual e reprodutiva, Cabo Verde, África Ocidental 


\section{Introduction}

In Cape Verde, as in other countries, there is a high prevalence of use of some kind of method of contraception, especially those which also furnish protection from sexually transmitted diseases (STDs), such as condoms. ${ }^{1,2}$ In Cape Verde, the prevalence of contraception use is considered to be high: over $75 \%$ of married men and women. ${ }^{3}$ Taking all women to be sexually active, $57.6 \%$ use some form of contraception, of whom $42.5 \%$ use the pill, $20.5 \%$ condoms and $37.0 \%$ other methods. ${ }^{3}$ Among Cape Verdian adolescents aged between 15 and 19 years, the prevalence of use of some kind of contraception during the last act of sexual intercourse was $50.6 \% .^{3}$ Similar studies have shown that, in most countries in sub-Saharan Africa, no more than $20 \%$ of adolescents use contraception. ${ }^{2}$ It is estimated that a large percentage of female adolescents in sub-Saharan Africa do not have access to contraception, the figure ranging from 15 to $32 \%$ in Zimbabwe and Rwanda. 4,5

Furthermore, studies suggest 6,7 a concentration of fecundity within a shorter interval of the reproductive period, occasioned by the increase in the fecundity of women aged under 20 years of age, in combination with a reduction in the fecundity of women aged over 20.8 This phenomenon is known as the rejuvenation of fecundity. 6

A similar pattern has emerged in developing countries, including Cape Verde, since the 1960s, to that which has been occurring in industrialized countries since the second half of the 19th century. In Cape Verde there was an increase of roughly $2.8 \%$ in fecundity rates among the 15-19 year age group, between 1990 and 2000. Thus, while in 1990 eleven out of every 100 women aged between 15 and 19 years had a child, by 2000 , this figure had risen to 11.3 per 100 women. $^{7}$

The sexual and reproductive behavior of adolescents is another relevant factor, since this has an impacto $\mathrm{n}$ the prevention of HIV. Some forms of contraception are thus considered important for protecting health.

The literature on African countries 1,9 especially those in sub-Saharan Africa, is quite scant, and, especially in Cape Verde, there is no information on factors associated with the use of contraception during sexual intercourse. 1,9

The present study aims to estimate the prevalence of contraceptive use and to determine the factors associated with its use among sexually active adolescents.

\section{Methods}

A cross-sectional study was carried out with a probabalistic and representative sample of adolescents living on Santiago Island, Cape Verde, between January and March 2007.

The inclusion criteria were: age between 13 and 17 years, attending secondary school on Santiago Island, and being sexually active.

A multi-stage probabalistic sampling technique was used. Stage 1 involved sampling by strata, stratified by municipality, with random selection of schools for each municipality. Stage 2 involved sampling by group, the population being divided up by school, and school years selected randomly from all the selected schools, followed by drawing up a list of all students meeting the inclusion criteria in each school year selected. The data sources used to obtain the sample parameters used were: the 2000 Population Census, 10 the 2004 - 2005 Annual of Statistics 11 and the principal's office of every school on the island. The latter furnished up to date information on the number of students, school years and grades during the study period.

The sample size was calculated on the basis of the percentage of sexually active adolescents $(83.6 \%)$, taking the sampling error to be $3.0 \%$ with a level of confidence of $95.0 \%$. For a population of 25,618 students, the size of each estimated sample was 576 individual adolescents, which was subsequently corrected for the finite population, to which $33.0 \%$ was added, to compensate for any wastage. The final sample thus comprised 768 adolescents attending secondary school, with between 7 and 12 years of schooling, as there was no register of students from this age group attending school in the evening.

All six municipalities on the island were covered by the study. The population included 23,761 individual students from 563 different classes and 16 different schools. Seven hundred and sixty-eight students were randomly selected, from 160 classes in eight schools (96 adolescents per school).

The adolescents were first invited to participate in the study and, once their consent had been obtained, their parents were consulted. Consent was established by way of meetings to explain the research objectives and procedures to the adolescents and their parents, to provide clarification with regard to the voluntary nature of participation and to gua-rantee that the information obtained would be strictly confidential and used only for scientific purposes. The parents were then requested to sign a informed consent form. Students selected for inclu- 
sion in the study were allowed time off school to fill in the self-applied questionnaire. This procedure took place in a single room and lasted 50 minutes. No student or parent or legal guardian refused to give consent.

The study was approved by the Research Ethics Committee of the University of São Paulo's Faculty of Public Health and was in compliance with the regulations governing research involving human beings contained in Resolutions no 196/96 and 251/97 of the Brazilian Ministry of Health's National Health Council.

In 2002, the World Health Organization 12 defined an adolescent chronologically as an individual aged between 10 and 19 years of age. Nevertheless, this study restricted itself to those aged between 13 and 17 years, on the grounds that 1) some of the questions related to sexual practices 2) this age group covers the period of sexual initiation and intermediate period of sexual activity among adolescents; and 3) more than half (58\%) of secondary school students on the whole archipelago fall into this age bracket. Four hundred adolescents who had not yet engaged in sexual activity were excluded from the study. The final sample therefore totaled 368 sexually active adolescents.

Once data had been gathered, a data base was set up in duplicate using the CSPro 6.0 software. For analysis this was transferred to the STATA 10 software.

The Anderson-Darling test was used to confirm the normality of the distribution for age, age on first menstruation, and age on initiation of sexual activity.

The descriptive analysis was presented in the form of proportions, means and standard-deviations. Differences in the proportions between the groups who did and did not use contraception were, initially, compared individually for each factor using Pearson's chi-squared test or Fisher's exact test. These groups were then compared for the various associated factors.

Associated factors with $\mathrm{p}$ values $<20 \%$ on univariate analysis were included in the Poisson multiple regression model with robust estimate of variance. At this stage the data were analyzed hierarchically, with the variables relating to behavior at the proximal level and the socio-demographic variables at the distal. The level of significance was set at $5 \%$.

The dependent variable was use of contraception during the last act of sexual intercourse. The adolescents were asked: "did you use some form of contraception to prevent pregnancy or contracting STDs during your last act of sexual intercourse?". The independent variables were: socio-demographic - age, municipality of origin, sex, level of schooling, religion, and exposure to mass media (having a TV or a radio); behavioral - having a regular sexual partner, having dated prior to the period covered by the study, a medical history of STDs, use of contraception during the first act of sexual intercourse, age on first menstruation and initiation of sexual activity, and consumption of tobacco and alcoholic beverages.

This study considered adolescents to be "single," if they could have had a regular sexual partner but did not have one during the period covered by the study.

\section{Results}

About seven out of ten adolescents reported having used some kind of contraception during their last act of sexual intercourse, most frequently a condom $(94.9 \%)$ or the pill $(26.4 \%)$ (Table 1$)$.

The mean age of adolescents who had used some form of contraception during their last act of sexual intercourse was $16.1(\mathrm{SD}=1.3)$ years, which differed significantly from the mean age of those who had not (mean $=15.6 ; \mathrm{SD}=1.4$ ), with $p=0.03$.

More than two thirds reported having dated on at least one occasion. Of these, almost all those who were single had used some kind of contraception. The proportion of adolescents who used some kind of contraception among those who were in some type of regular sexual relationship was $96.2 \%$ and tended to increase with age, rising frome $4.9 \%$ among adolescents aged 13 years to $58.3 \%$ among those aged 17.

The percentage who used contraception was $96.2 \%$ among smokers and $100 \%$ among nonsmokers. Of adolescents who consume alcoholic beverages, the proportion of contraceptive use was $94.7 \%$, which is comparable to that of those who do not drink (96.6\%). Table 2 shows the factors significantly associated with use of some kind of contraceptive, the dependent variable being the use of some form of contraception during the last act of sexual intercourse.

On multiple analysis, three factors retained their singificant positive association with the use of contraception: living in the capital city $(\mathrm{PR}=1.23$; CI95\%: $1.07 ; 1.39)$, having sexual relations with a single regular partner ( $\mathrm{PR}=1.53$; CI95\%: 1.14;2.06); and having more than nine years of schooling $(\mathrm{PR}=1.19$; CI95\%: 1.02; 1.38). 
Distribution of adolescents by contraceptive use and likely associated variables. Santiago Island, Cape Verde, 2007.

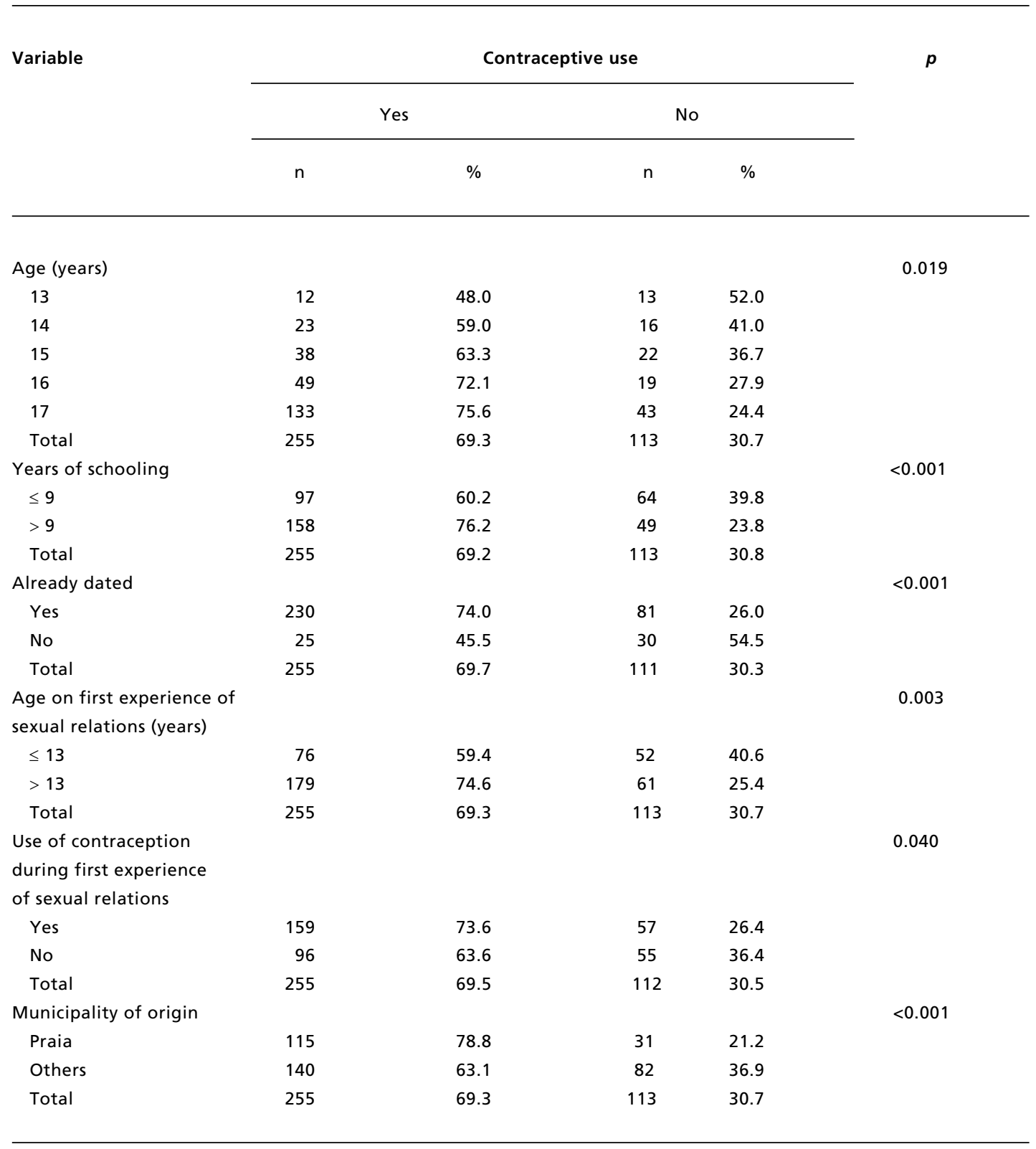

Note: Co-variables for which $p$ was not $<20 \%$ in the univariate analysis are not shown, namely: sex, awareness of contraception, marital status, alcohol consumption, tobacco consumption, exposure to the mass media (having a TV and a radio), religion, and already having had some kind of sexually transmitted disease. 
Estimated adjusted prevalence ratio (PR) of use of contraception during last act of sexual intercourse. Santiago Island. Cape Verde, 2007.

\begin{tabular}{|c|c|c|c|c|c|c|}
\hline \multirow[t]{2}{*}{ Variable } & \multicolumn{4}{|c|}{ Model 1* } & \multicolumn{2}{|l|}{ Model 2** } \\
\hline & PR & $\mathrm{Cl} 195 \%$ & $p$ & PR & $\mathrm{Cl} 195 \%$ & $p$ \\
\hline \multicolumn{7}{|l|}{ Already dated } \\
\hline No & 1.00 & & & 1.00 & & \\
\hline Yes & 1.53 & $(0.90 ; 2.37)$ & 0.055 & 1.53 & $(1.14 ; 2.06)$ & 0.005 \\
\hline \multicolumn{7}{|c|}{ Use of contraception during } \\
\hline \multicolumn{7}{|c|}{ first sexual relation } \\
\hline No & 1.00 & & & 1.00 & & \\
\hline Yes & 1.11 & $(0.66 ; 1.87)$ & 0.670 & 1.90 & $(0.64 ; 1.70)$ & 0.580 \\
\hline \multicolumn{7}{|c|}{ Age on first sexual relation } \\
\hline 11-12 years & 1.00 & & & 1.00 & & \\
\hline 13 or more & 0.99 & $(0.92 ; 1.07)$ & 0.821 & 0.99 & $(0.95 ; 1.03)$ & 0.668 \\
\hline \multicolumn{7}{|l|}{ Age band } \\
\hline$\leq 14$ years & 1.00 & & & 1.00 & & \\
\hline$>14$ years & 1.22 & $(0.66 ; 2.24)$ & 0.532 & 1.21 & $(0.83 ; 1.78)$ & 0.319 \\
\hline \multicolumn{7}{|c|}{ Years of schooling } \\
\hline$\leq 9$ & 1.00 & & & 1.00 & & \\
\hline$>9$ & 1.19 & $(0.90 ; 1.57)$ & 0.233 & 1.19 & $(1.02 ; 1.38)$ & 0.029 \\
\hline \multicolumn{7}{|c|}{ Municipality of origin } \\
\hline Others & 1.00 & & & 1.00 & & \\
\hline Praia & 1.22 & $(0.95 ; 1.56)$ & 0.119 & 1.23 & $(1.07 ; 1.39)$ & 0.003 \\
\hline
\end{tabular}

\section{Discussion}

The present study is the first in Cape Verde to estimate the prevalence of contraceptive use among adolescents, in particular, during the last act of sexual intercourse, and the possible factors associated with contraceptive use.

The use contraception in Cape Verde is very widespread, which is different from the findings of studies involving married female adolescents in other sub-Saharan countries $(<20 \%), 2,13$ Haiti $(28 \%)^{13}$ and even Brazil (around 46\%). ${ }^{2}$ The data presented in this study suggest a figure of $69.3 \%$ of adolescents aged between 13 and 17 years, which is consistent with the $50.6 \%$ found among adolescents aged between 15 and 19 years in Cape Verde by a study conducted by the Cape Verde National
Institute of Statistics Cape Verde. ${ }^{1}$

The widespread use of contraception in Cape Verde is a consequence of public policy, such as, for example, the free distribution of oral contraceptive pills, condoms, intrauterine devices, and the introduction of sexual and reproductive education in schools. It is thus possible to state the contraception is a right to health in Cape Verde, differently from other countries in the sub-Saharan region. ${ }^{14,15}$ Understanding that contraception as a human right has contributed greatly to reducing fecundity and preventing transmission of HIV among adolescents and young people. As a result of this, in Cape Verde, the prevalence of HIV is relatively low, ${ }^{3}$ ranging from $0.8 \%$ to $1.5 \%$ of the population, in contrast to 
other countries in sub-Saharan Africa, where the epidemic appears to have stabilized at a prevalence of $7.4 \% .16$

Contraceptive use has been the most important method of controlling fecundity, bringing about a reduction of 4.3 children in the total fecundity rate in Cape Verde, in 1998.7

In the specific case of male condom use, $84.7 \%$ of adolescents living on Santiago Island report using this method of contraception during their first experience of sexual relations. ${ }^{1}$ This further demonstrates how Cape Verde stands out in comparison with other developing countries, especially those in subSaharan Africa. 1,13 Cape Verde has also outstripped Brazil, as studies carried out among adolescents aged between 12 and 19 years in the city of João Pessoa (in the State of Paraíba), and among those aged between 16 and 18 years in the municipality of Marília (in the State of São Paulo), 42.9\% and $45.4 \%$, respectively claimed to have used a condom during their first experience of sexual intercourse. 16

Cape Verde also has good results in terms of the use of oral contraception during the last act of sexual intercourse. In Marília, $63.6 \%$ of adolescents, in 2005,16 reported use of this method, which is more than twice as many as the number found in the present study (26.4\%). There is, however, a better balance between the use of condoms and oral contraception in Cape Verde than in Brazil.

Adolescents who stated that they were dating at the time when the research was carried out were more likely to have used contraception ( $50 \%$ more) during the last act of sexual intercourse than those who had never dated. On the other hand, studies 17,18 show that female adolescents who cohabit with a partner use condoms less frequently, owing to the lack of negotiating power.

No association was found between contraception use during the last act of sexual intercourse and the variables that have been described in the literature, such as: sex female vs. male, 19 awareness regarding contraception, 19,20 marital status, 20,21 age on first experience of sexual relations, 22 and others. It is reasonable to believe that such differences are not to be found in Cape Verde, as the social context is conducive to contraceptive use, as a result of a public policy of raising awareness and distributing condoms and oral contraceptives. Individual factors do not therefore seem to have a significant effect, as they do in other countries, developed or not.

So far as factors associated with contraceptive use during the last act of sexual intercourse are concerned, the absence of any statistical association with awareness regarding contraception, which concurs with another Brazilian study among adolescents aged between 11 and 19 years, ${ }^{19}$ shows that a high level of awareness regarding contraception is not necessarily associated with its use.

Inadequate knowledge regarding contraception may be a factor determining resistence towards its use. ${ }^{23}$ On the other hand, a high level of awareness in this regard will not necessarily lead to changes in behavior, if contraceptives are not made available and adolescents are not free to use them.

The choice of contraceptive method among adolescents should be free and informed, as is the case with other age groups. Ease of access to to information on sex does not automatically guarantee better protection against STDs and unplanned pregnancies. 24 On the other hand, ignorance with regard to sex and contraceptive methods may lead to a rise in the incidence of unplanned pregnancy, HIV and STD among adolescents.

In Cape Verde, therefore, in the female population (adult, young and adolescent), two particular kinds of contraception tend to dominate: the condom and the pill,24 which is different from countries such as Brazil, where the pill and sterilization tend to be the principal methods of contraception. 24 Access to good quality information and the availability of alternative methods of contraception are fundamental components of family planning programs aimed not only at adolescents but at the general population.

Age is probably directly related to contraceptive use, in such a way that, the older the adolescent, the more likely they are to some form of contraception. 25,26 This is also born out by our study, which shows older adolescents to be more likely to use contraception.

Schooling is another fundamental variable for sex education, especially so far as prevention of pregnancy in adolescence is concerned. This variable has ben shown to be important in explaining contraceptive behavior in similar studies, 27,28 indicating that education has a positive effect on the use of contraceptives. ${ }^{27}$ Our findings, likewise, show a positive association between level of schooling and contraceptive use among adolescents.

Khan et al. 28 have shown that women living in an urban environment are 1.24 times more likely to use contraception than those living in a rural area.

A number of methodological features of the present study should be borne in mind. No individual refused to take part in the study.

Although the sample is representative of the totality of secondary schools on Santiago Island, the results of the present study, in common with other 
similar ones, are susceptible to self-reporting bias on the part of the adolescents. ${ }^{1}$

The variables sex, age on first experience of sexual relations, and alcohol and tobacco consumption are important indicators for investigation of sexual and reproductive health. However, these variables did not have any impact on the prevalence of contraceptive use in the present study. On the other hand, older adolescents, who studied in Praia (the capital city) and who were dating at the time of the interview were most likely to use contraception. These findings, in particular the high prevalence of condom use and the association between level of schooling and condom use among adolescents, may provide evidence of positive results of current sexual and reproductive health policies, thereby helping to reduce rates of HIV infection.

\section{References}

1. Tavares CM, Schor Néia, França Junior I, Diniz SG. Factors associated with sexual initiation and condom use among adolescents on Santiago Island, Cape Verde, West Africa Cad Saúde Pública. 2009; 25: 1969-80.

2. Alan Guttmacher Institute. Rumo a um novo mundo: A vida sexual e reprodutiva de mulheres jovens. New York: Alan Guttmacher Insititute; 1998. [acessado 2008 fev 29]. Disponível

http://www.guttmacher.org/pubs/new_world_port.html.

3. Instituto Nacional de Estatística de Cabo Verde. Inquérito demográfico e de saúde reprodutiva 2005. Praia: Instituto Nacional de Estatística de Cabo Verde; 2007.

4. Robey B, Ross J, Bhushan I. Meeting unmet need: new strategies. Popul Rep J. 1996; 43: 1-35.

5. Bhushan I. Understanding unmet need. Baltimore: Johns Hopkins School of Public Health; 1997. [Working Paper no 4].

6. Berquó ES. O rejuvenescimento da fecundidade. Palestra. In: Encontro Estadual de Políticas Públicas de Juventude; 2003; São Paulo, Brasil: promovido pelo Programa de Capacitação Solidária, 29 e 30 de setembro.

7. Tavares CM, Camarano AA, Abreu LC. Fecundidade de mulheres Cabo-Verdianas - África Ocidental. Rev Bras Crescimento Desenvol Hum. 2008; 18: 1-10.

8. Gupta N, Leite IC. Tendências e determinantes da fecundidade entre adolescentes no Nordeste do Brasil. Perspect Int Planej Fam. 2001;(N esp): 24-9.

9. Tavares CM. Adolescência e anticoncepção: iniciação sexual e uso de métodos anticoncepcionais em adolescentes da Ilha de Santiago, Cabo Verde - África Ocidental [tese]. São Paulo: Faculdade de Saúde Pública da USP; 2009.
It is recommended that longitudinal studies that use the same methodology as the present study be carried out among public secondary school studients, which could corroborate or complement the data on factors associated with the prevalence of contraceptive use on the Island of Santiago.

\section{Acknowledgements}

We wish to express our thanks to the Post-Graduate Exchange-Students Programme PEC-PG, to CAPES for financial support and to Professor Cláudio Leone for his invaluable assistance with interpretation and analysis of the results.

10. Instituto Nacional de Estatística de Cabo Verde. Censo demográfico 2000. Praia: Instituto Nacional de Estatística de Cabo Verde; 2002.

11. Ministério da Educação. Gabinete de Estudos e Planeamento do Ministério de Educação e Valorização de Recursos Humanos. Anuário Estatístico 2004 - 2005. Praia; 2005.

12. World Health Organization. Adolescent friendly health services - an agenda for change. Geneva; 2002.

13. Khan S, Mishra V, Arnold F, Abderrahim N. Contraceptive Trends in Developing Countries. Calverton: ORC Macro. DHS working papers, 16, 2007.

14. Cape Verde: Progress towards Universal Access and The. Declaration of Commitment on HIV/AIDS. Data from Cape Verde UNGASS country progress reports (2003, 2005 and 2007) and additional correspondence with country.[acessado 2009 out. 3]. Disponível em: http://data.unaids.org/pub/Report/2008/cape_verde_2008_c ountry_progress_report_fr.pdf.

15. Diniz C, Simone G, França Junior I. Anticoncepção e direitos humanos. In: Aldrighi JM, Petta CA. (Org.). Anticoncepção: aspectos contemporâneos. São Paulo: Editora Atheneu; 2004. p. 209-16

16. Rojas SHCC, Crestani KD, Batista GV, Melo APA Características reprodutivas das adolescentes da legião mirim de Marília - São Paulo, Brasil, 2005. DST J Bras Doenças Sex Transm. 2006; 18: 137-42.

17. Clark S. 2004. Early marriage and HIV risks in sub-Saharan Africa. Stud Fam Plann. 2004; 35: 149-60.

18. Clark S, Bruce J, Dude A. Protecting young women from HIV/AIDS: The case against child and adolescent marriage. Int Fam Plan Perspect. 2006; 32: 79-88. 
19. Almeida MC, Aquino EM, Gaffikin L, Magnani RJ. Uso de contracepção por adolescentes de escolas públicas na Bahia. Rev Saúde Pública. 2003; 37: 566-75.

20. Sociedade Civil Bem-Estar Familiar no Brasil Adolescentes, jovens e a pesquisa nacional sobre demografia e saúde: um estudo sobre fecundidade, comportamento sexual e saúde reprodutiva. Rio de Janeiro: CDC/UNICEF; 1999.

21. Manning WD, Longmore MA, Giordano PC. The relationship context of contraceptive use at first intercourse. Fam Plann Perspect 2000;32:104-10

22. Narring F, Wydler H, Michaud PA. First intercourse and contraception: a cross-sectional survey on the sexuality of 16-20-year-olds in Switzerland. Schweiz Med Wochenschr 2000;130:1389-98

23. Espejo X, Tsunechiro MA, Osis MJ, Duarte GA Bahamondese L, Sousa MH. Adequação do conhecimento sobre métodos anticoncepcionais entre mulheres de Campinas, São Paulo. Rev Saúde Pública. 2003; 37: 583 90 .

Recebido em 17 de julho de 2009

Versão final apresentada em 3 de março de 2010

Aprovado em 30 de abril de 2010
24. Campos MAB. Gravidez na Adolescência. A imposição de uma nova identidade. Pediatr Atual. 2000; 13: 25-6.

25. Adair T. Men's condom use in higher-risk sex:trends and determinants in five sub-saharan countries. Calverton: ORC Macro; 2008. [DHS working papers $n^{\circ} 34$ ].

26. Schor N, França AP, Siqueira AAF, Pirotta KCM, Alvarenga AT. Adolescência: vida sexual e anticoncepção. In: 11o Encontro Nacional de Estudos Populacionais da ABEP - População, globalização e exclusão, 1998, Caxambu/MG. Anais do 11. Encontro Nacional de Estudos Populacionais da ABEP - População, globalização e exclusão. Caxambu/MG: ABEP, 1998. v.1. p. 232-67.

27. Giffin K. Pobreza, desigualdade e equidade em saúde: considerações a partir de uma perspectiva de gênero transversal. Cad Saúde Pública. 2002; 18 (Supl): 103-12.

28. Khan S, Mishra V, Arnold F, Abderrahim N. Contraceptive Trends in Developing Countries. Calverton: ORC Macro; 2007. [DHS working papers no 16]. 